\title{
WORLD FEDERATION OF SOCIETIES OF ANESTHESIOLOGISTS
}

AT the first meeting of the General Assembly of the World Federation of Societies of Anesthesiologists the following officers were elected:

\author{
President \\ Dr. Harold R. GruFfith (Canada) \\ Vice-Presidents \\ Dr. C. R. Ritsema van Eck (Netherlands) \\ Dr. A. GoljBdat (Belgium) \\ Dr R. Frev (Gernhiany) \\ Dr. M. Cof.belo (Cuba)
}

Secretary-Treasurer

Dr Choffrey Organe (England)

\section{Executive Committee}

Dr. J Boufeau

Dr. E. Crocatto

Dr. J GLlles

Dr. A. Goldblat

Dr. T GoRdH

Dr. A. Gonzales Vareita

Dr R. A. Ciordon

Dr. H R GrifftTH

Dr. N. R. J AMMES

Dr. O. Mayrhofer

DR. R. P. W. SHACKLETON

Dr. ZaIro VIEIRA.

At a meeting of the Executive Committee on September 10, 1955, Dr. A. Goldblat was elected as Chairman and Dr. C R. Ritsema van Eck and Dr. S. G. Talwalkar were co-opted to the Executive Committee.

It was also agreed by the Executive Committee. that the Second General Assembly should take place during a Congress to be arranged for 1960 . 